\title{
Timer Device
}

National Cancer Institute

\section{Source}

National Cancer Institute. Timer Device. NCI Thesaurus. Code C50223.

A device designed to measure a time interval. 